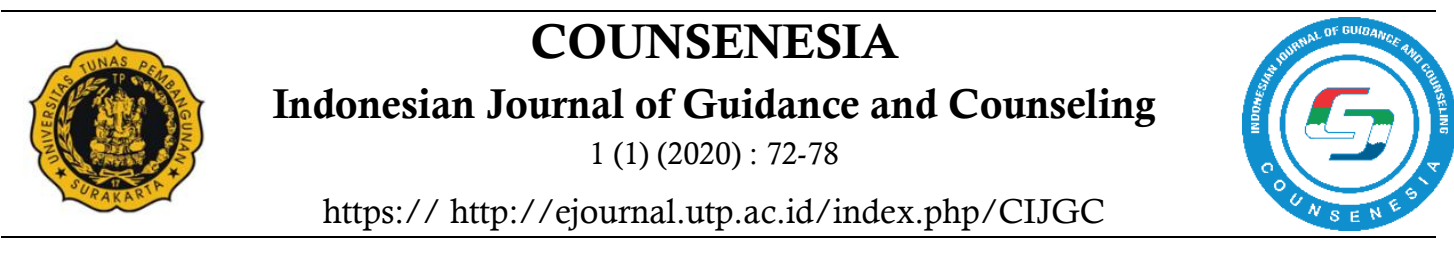

\title{
PENDIDIKAN DAN BUDAYA: PEMBENTUKAN KONSEP DIRI PESERTA DIDIK MINORITAS MELALUI KONSELING LINTAS BUDAYA
}

\author{
Annisah Fadila Taharani \\ Universitas Borneo Tarakan \\ Email: annisahfadila@students.unnes.ac.id
}

\begin{abstract}
Info Artikel Abstrak
Riwayat Artikel

Diterima:

November 2020

Disetujui:

Desember 2020

Publikasi:

Desember 2020

Indonesia merupakan negara yang kaya akan ragam budaya, setiap daerah memiliki keunikan dan ciri khas budaya masing-masing. Perbedaan budaya pada setiap daerah akan mempengaruhi konsep diri pada seseorang. Konsep diri merupakan keyakinan, pandangan maupun penilaian seseorang terhadap dirinya. Konsep diri yang dimiliki seseorang tidak bersifat genetik atau turunan bawaan dari orang tua tetapi ditentukan oleh hasil interaksi dengan lingkungannya baik orang tua maupun lingkungan disekitarnya. Konsep diri memiliki peranan yang sangat penting dalam menentukan perilaku seseorang dan masa depannya, oleh karena itu pendidikan sangat dibutuhkan sebagai upaya pembentukan konsep diri pada seseorang agar dapat berkembang dengan optimal. Konseling lintas budaya merupakan salah satu usaha yang dapat dilakukan dalam usaha pendidikan untuk membentuk konsep diri seseorang, dimana konseling lintas budaya berperan untuk membantu proses mendefinisikan tujuan yang konsisten dengan pengalaman hidup dan nilai-nilai budaya klien, mengenali identitas klien untuk memasukkan dimensi individu, kelompok, dan universal, mendukung penggunaan universal, strategi dan peran khusus budaya dalam proses penyembuhan, dan menyeimbangkan pentingnya individualisme dan kolektivisme.
\end{abstract}

Kata Kunci : Konsep diri, Peserta Didik Minoritas, Konseling Lintas Budaya

\begin{abstract}
Indonesia is a country that has a diverse culture, each region has unique and distinctive cultural characteristics. Cultural differences in each region will affect students' self-concept. The concept of self is the individual's beliefs, views and judgments on him, self-concepts that are not genetic or inherited from parents but are determined by the results of interaction with the environment both parents and the surrounding environment. Self-concept has a very important role in determining student behavior and the future, therefore education is needed as an effort to form self-concept in students in order to develop optimally. Cross-cultural counseling is one of the efforts can be made in educational efforts to shape students' self-concept, where cross-cultural counseling has a role in helping the targeting process that is consistent with the client's life experience and cultural values, recognizing the client's identity to include individual dimensions, group and universal, supporting universal use, strategies and specific roles of culture in the healing process, and balancing the importance of individualism and collectivism.
\end{abstract}

Keywords: Self-Concept, Minority Students , Cross-Cultural Counseling 


\section{PENDAHULUAN}

Indonesia merupakan negara kesatuan yang memiliki beragam budaya, setiap daerah memiliki keunikan dan ciri khas budaya masing-masing. Berry dkk dalam Matsumoto (2013) menerangkan budaya adalah gambaran kegiatan atau perilaku, warisan maupun tradisi dari suatu kelompok, yang memiliki aturan dan norma, serta terdapat pembelajaran atau cara pemecahan masalah, pendefinisian organisasi kelompok serta hal-hal yang merujuk pada asal-usul kelompok. Sedangkan Murdock dkk dalam Matsumoto (2013) menjelaskan budaya merupakan karakteristik tertentu dari sandang pangan; perumahan dan teknologi; ekonomi dan transportasi; kegiatan individu dan keluarga; komunitas dan pemerintah; kesejahteraan, agama, dan sains; dan seks dan siklus kehidupan.

Keberagaman budaya yang ada di Indonesia sangat berpengaruh pada tatanan kehidupan masyarakatnya seperti mempengaruhi gaya hidup, kebiasaan masyarakat, tingkah laku, keyakinan dan nilai-nilai yang dianut hingga aturan-aturan serta norma yang ada dimasyarakat. Selain itu keberagaman budaya juga turut berpengaruh dalam lembaga pendidikan Indonesia. Lembaga pendidikan merupakan lembaga yang berperan besar dalam mencetak sumber daya manusia yang berkualitas dan berkarakter.

Dalam lembaga pendidikan juga terdapat keberagaman budaya ditunjukan dengan adanya perbedaan latar belakang budaya antara pendidik dan para peserta didik, hal ini membuat pentingnya seorang guru bimbingan dan konseling memahami latar belakang budaya dari para peserta didik agar dapat mendidik dan membimbing peserta didik lebih optimal baik dalam bidang belajar, pribadi karir maupun sosialnya serta mencapai tugastugas perkembangannya, salah satunya tugas perkembangannya adalah mencapai identitas diri, seorang remaja mampu menilai diri sendiri baik atau tidaknya tergantung pada pemahaman peserta didik terhadap konsep dirinya.

Perbedaan budaya pada setiap daerah juga mempengaruhi konsep diri pada seorang peserta didik, hal ini sesuai dengan Matsumoto (2013) yang menerangkan dalam bukunya bahwa konsep diri itu berakar pada pandangan terhadap budaya, dan pandangan terhadap budaya tersebut berbeda-beda, maka konsep diri dari setiap budaya juga berbeda. Seperti yang diketahui perbedaan-perbedaan konsep diri ini terjadi karena budaya yang berbeda, sistem aturan hidup yang berbeda, kondisi sosial dan lingkungan ekonomi serta habitat alam yang berbeda. Tuntutan budaya yang pada anggota individu menuntut individu mengintegrasikan, mensintesis, serta mengkoordinasikan dunia mereka dalam berbagai cara sehingga menghasilkan perbedaan konsep diri.

Konsep diri sendiri merupakan keyakinan, pandangan maupun penilaian seseorang terhadap dirinya seperti yang dijelaskan oleh Saraswat dan Gaur dalam Waghmare (2018) konsep diri merupakan kemampuan berpikir seorang individu dan keyakinan terhadap dirinya sendiri. Dia menambahkan pula bahwa Konsep diri adalah kesan terhadap diri sendiri serta sekumpulan gagasan \& pemikiran tentang dirinya sendiri. Konsep diri memiliki peranan yang sangat penting dalam menentukan perilaku seseorang individu dan masa depannya. Konsep diri yang dimiliki seseorang tidak bersifat genetik atau turunan bawaan dari orang tua tetapi konsep diri di pengaruhi oleh banyak faktor seperti, lingkungan keluarga seseorang, lingkungan sekolah, tingkat status sosial ekonomi, kelompok sebaya, dll.

Dalam upaya mendidik dan membimbing peserta didik untuk mencapai identitas diri dan berkembang lebih optimal baik dalam bidang belajar, karir, pribadi dan sosialnya sangat diperlukan peran guru bimbingan dan konseling dengan layanan konseling lintas budaya disekolah agar dapat membantu proses mendefinisikan tujuan yang konsisten dari 
pengalaman hidup dan nilai-nilai budaya peserta didik, mengenali Identitas peserta didik untuk memasukkan dimensi individu, kelompok, dan universal, mendukung penggunaan universal dan strategi dan peran khusus budaya dalam proses konseling, dan menyeimbangkan pentingnya individualisme dan kolektivisme. Selain itu D'Andrea dan Daniels (1995) mendefinisikan tentang konseling lintas budaya lebih spesifik yaitu sebuah proses di mana seorang profesional terlatih dari satu latar belakang budaya / etnis / ras berinteraksi dengan klien dari latar belakang budaya / etnis / ras yang berbeda untuk tujuan mempromosikan pengembangan kognitif, emosional, psikologis, dan / atau spiritual klien

\section{PEMBAHASAN}

\section{Konsep Diri}

Konsep diri dapat diartikan sebagai persepsi atau pandangan maupun penilaian individu terhadap dirinya sendiri, Saraswat dan Gaur dalam Waghmare (2018) menerangkan bahwa konsep diri merupakan kemampuan berpikir seorang individu dan keyakinan terhadap dirinya sendiri. Dia menambahkan pula bahwa Konsep diri adalah kesan terhadap diri sendiri serta sekumpulan gagasan \& pemikiran tentang dirinya sendiri. Sedangkan Jacinta F. Rini (dalam Murmanto,2007) mengartikan konsep diri secara umum sebagai keyakinan, pandangan atau penilaian seseorang terhadap dirinya. Burns (dalam Anissa dan Handayani, 2012) konsep diri adalah suatu gambaran campuran dari apa yang kita pikirkan, orang-orang lain berpendapat mengenai diri kita, dan seperti apa diri yang kita inginkan. Hal ini sesuai dengan Hurlock (2011) yang menjelaskan bahwa konsep diri adalah konsep seseorang dari siapa dan apa dia itu. Konsep ini seperti bayangan pada cermin, sebagian besar ditentukan oleh peran dan hubungan dengan orang lain, dan apa yang kiranya reaksi orang lain terhadapnya. Konsep diri mencakup citra diri fisik dan psikologis. Citra diri fisik biasanya berkaitan dengan penampilan, sedangkan citra diri psikologis berdasarkan atas pikiran, perasaan, dan emosi.

\section{Peserta Didik Minoritas}

Peserta didik merupakan sumber utama dan terpenting dalam proses pendidikan formal (Danim, 2010). Sedangkan Menurut Wikipedia (2018) Peserta didik adalah anggota masyarakat yang berusaha mengembangkan potensi diri melalui proses pembelajaran pada jalur pendidikan baik pendidikan informal, pendidikan formal maupun pendidikan nonformal, pada jenjang pendidikan dan jenis pendidikan tertentu. Hal ini sejalan dengan definisi peserta didik dalam Undang-Undang Nomor 20 Tahun 2003 yaitu peserta didik adalah anggota masyarakat yang berusaha mengembangkan potensi diri melalui proses pembelajaran yang tersedia pada jalur, jenjang, dan jenis pendidikan tertentu.

Minoritas Menurut Kamus Besar Bahasa Indonesia (KBBI) adalah kelompok sosial yang jumlah populasinya jauh lebih kecil dibandingkan dengan kelompok yang lain. sedangkan menurut Mendatu (2010) definisi dari minoritas adalah kelompok sosial yang secara signifikan lebih kecil dari kelompok lain di dalam sebuah komunitas lebih lanjut Mendatu (2010) menjelaskan jika secara umum definisi minoritas berkaitan dengan jumlah, berbeda halnya dengan sudut pandang ilmu sosial yang menyatakan bahwa minoritas tidak selalu terkait dengan jumlah anggota, melainkan sebuah kelompok dikatakan minoritas mana kala anggotanya memiliki kekuasaan atau pengaruh yang lemah dalam kehidupannya sendiri jika dibandingkan dengan anggota kelompok yang lebih dominan.

Berdasarkan definisi diatas maka peserta didik minoritas adalah kelompok peserta didik yang jumlahnya anggotanya secara signifikan lebih kecil dari pada yang kelompok 
yang lain didalam lingkungan tersebut, misalnya berkaitan dengan agama dan suku, namun konsep ini menjelaskan tentang peserta didik minoritas yang tekait suku yang berbeda.

\section{Konseling Lintas Budaya}

Konseling lintas budaya berperan untuk membantu proses mendefinisikan tujuan yang konsisten dengan pengalaman hidup dan nilai-nilai budaya klien, mengenali Identitas klien untuk memasukkan dimensi individu, kelompok, dan universal, mendukung penggunaan universal dan strategi dan peran khusus budaya dalam proses penyembuhan, dan menyeimbangkan pentingnya individualisme dan kolektivisme dalam penilaian, diagnosis, dan perawatan klien dan sistem klien (D. W. Sue \& Torino dalam Ratss, 2014). Selain itu D'Andrea dan Daniels dalam Ratss (2014) mendefinisikan tentang konseling lintas budaya lebih spesifik yaitu sebuah proses di mana seorang profesional terlatih dari satu latar belakang budaya / etnis / ras berinteraksi dengan klien dari latar belakang budaya / etnis / ras yang berbeda untuk tujuan mempromosikan pengembangan kognitif, emosional, psikologis, dan spiritual klien.

Sedangkan Sue dan Sue dalam Ratss dan Pedersen (2014) menawarkan definisi yang lebih mutakhir tentang konseling multikultural yang berbicara tentang peran dan proses, dimana peran dan proses membantu dengan menggunakan modalitas dan tujuan untuk mendefinisikan secara konsisten dengan menggunakan pengalaman hidup dan nilai-nilai budaya klien untuk mengenali identitas klien dan memasukkan dimensi individu, kelompok dan universal, selain itu juga untuk mendukung penggunaan strategi dan peran khusus universal dan budaya dalam proses konseling dan menyeimbangkan pentingnya individualisme dan kolektivisme dalam penilaian, diagnosis, dan perawatan klien dan sistem klien. Adapun kompetensi yang harus dimiliki oleh konselor multicultural adalah :

1. Kesadaran Terapis tentang Asumsi, Nilai, dan Bias

Konselor profesional yang kompeten secara budaya adalah orang yang aktif dalam proses menjadi sadar akan anggapannya sendiri tentang perilaku manusia, nilai, bias, prasangka yang terbentuk sebelumnya, keterbatasan pribadi, dan sebagainya.

2. Memahami Pandangan tentang Klien yang Beragam Budayal

Sangat penting bahwa konselor dan terapis memahami dan dapat berbagi pandangan dunia dari klien mereka yang beragam secara budaya. Pernyataan ini tidak berarti bahwa penyedia harus memegang pandangan dunia ini sebagai milik mereka sendiri, tetapi lebih bahwa mereka dapat melihat dan menerima pandangan dunia lainnya dengan cara yang tidak menghakimi.

3. Mengembangkan Strategi dan Teknik Intervensi yang Tepat

Efektivitas kemungkinan besar ditingkatkan ketika terapis menggunakan modalitas terapeutik dan mendefinisikan tujuan yang konsisten dengan pengalaman hidup dan nilai-nilai budaya klien. Transaksi interpersonal antara konselor dan klien memerlukan berbagai pendekatan yang konsisten dengan pengalaman hidup seseorang.

Selain itu dalam proses pemberian bantuan seorang konselor harus dapat berlaku adil dan tidak memihak serta Untuk terjadinya terapi yang efektif, terapis dan klien harus dapat mengirim dan menerima pesan baik verbal dan nonverbal secara tepat dan akurat. Sementara kerusakan dalam komunikasi sering terjadi antara orang-orang yang berbagi budaya yang sama, masalah menjadi diperburuk antara orang-orang dari latar belakang ras atau etnis yang berbeda. Kesalahpahaman yang timbul dari variasi budaya dalam komunikasi dapat menyebabkan keterasingan atau ketidakmampuan untuk mengembangkan kepercayaan dan hubungan. 
Sue \& Sue (2008) menyebutkan tiga karakteristik utama dari konseling dan psikoterapi dapat bertindak sebagai hambatan untuk konseling yang efektif

1. Nilai yang terkait budaya

Nilai yang terkait budaya menjadi salah satu hambatan dalam konseling karena terkait dengan bentuk respon emosional, perilaku, komunikasi, pola hubungan (keintiman dan keterbukaan) serta perbedaan pandangan yang kentara. Beberapa karakteristik nilai terkait budaya yang bertanggung jawab untuk ini keyakinan negatif

2. Nilai yang terkait kelas sosial

Bentuk karakteristik hambatan dalam konseling karena nilai yang terkait sosial adalah mengenai kepatuhan yang ketat terhadap jadwal konseling, pendekatan yang ambigu atau tidak terstruktur untuk masalah, dan solusi mencari tujuan jangka panjang

3. Hambatan bahasa

Bahasa merupakan alat yang digunakan individu untuk dapat bertukar informasi secara verbal. Melalui bahasa maka individu dapat bertukar sikap, nilai, keyakinan, dan perilaku sehingga dapat terus diwariskan dari satu generasi kegenerasi berikutnya akan terjadi bias dalam konseling multicultural.

\section{Pengembangan Konsep Diri Peserta Didik Minoritas Melalui Konseling Lintas Budaya}

Konsep diri dapat diartikan sebagai persepsi atau pandangan maupun penilaian individu terhadap dirinya sendiri, Saraswat dan Gaur dalam Waghmare (2018) menerangkan bahwa konsep diri merupakan kemampuan berpikir seorang individu dan keyakinan terhadap dirinya sendiri. Dia menambahkan pula bahwa Konsep diri adalah kesan terhadap diri sendiri serta sekumpulan gagasan \& pemikiran tentang dirinya sendiri.

Peserta didik minoritas adalah kelompok peserta didik yang jumlahnya anggotanya secara signifikan lebih kecil dari pada yang kelompok yang lain didalam lingkungan sekolah. Dan seperti yang kita ketahui sebelumnya lingkungan sekolah menjadi faktor kedua utama setelah lingkungan keluarga dalam pembentukkan konsep diri, hal ini karena lingkungan sekolah merupakan lembaga yang berperan besar dalam mencetak sumber daya manusia yang berkualitas, selain itu lingkungan sekolah juga tidak lepas dari keberagaman budaya yang ada di Indonesia, di dalam lingkungan sekolah terdapat berbagai budaya yang berbeda hal ini terjadi karena para pendidik dan peserta didik berasal dari latar belakang budaya yang berbeda, adapun perbedaan yang terjadi dalam lingkungan sekolah akibat keberagaman budaya adalah: (a) perbedaan bahasa, (b) agama, (c) suku, (d) budaya, (e) cara pandang yang berbeda (d) perbedaan kelas sosial.

Sedangkan dampak dari perbedaan budaya tersebut terhadap peserta didik minoritas dapat membuat peserta didik mudah terpengaruh dan kehilangan identitats diri hal ini terjadi akibat perbedaan antara konsep dari latar belakang budaya yang telah dianut dengan budaya baru yang mereka hadapi, untuk itu dalam hal ini peran guru BK sangat dibutuhkan agar dapat membantu peserta didik sukses mencapai identitas dirinya, adapun upaya yang dapat dilakukan guru BK dalam membantu peserta didik minoritas tersebut adalah dengan menggunakan layanan konseling lintas budaya agar dapat membantu proses mendefinisikan tujuan yang konsisten dengan pengalaman hidup dan nilai-nilai budaya klien, mengenali Identitas klien untuk memasukkan dimensi individu, kelompok, dan universal, mendukung penggunaan universal dan strategi dan peran khusus budaya dalam proses penyembuhan, dan menyeimbangkan pentingnya individualisme dan kolektivisme dalam penilaian, diagnosis, dan perawatan klien dan sistem klien (D. W. Sue \& Torino, 2005). Selain itu D'Andrea dan Daniels (1995) mendefinisikan tentang konseling lintas 
budaya lebih spesifik yaitu sebuah proses di mana seorang profesional terlatih dari satu latar belakang budaya / etnis / ras berinteraksi dengan klien dari latar belakang budaya / etnis / ras yang berbeda untuk tujuan mempromosikan pengembangan kognitif, emosional, psikologis, dan / atau spiritual klien.

\section{PENUTUP}

Konsep diri dapat diartikan sebagai persepsi atau pandangan maupun penilaian individu terhadap dirinya sendiri. Sedangkan peserta didik minoritas adalah kelompok peserta didik yang jumlah anggotanya secara signifikan lebih kecil dari kelompok yang lain didalam lingkungan sekolah. Lingkungan sekolah menjadi faktor utama yang kedua setelah lingkungan keluarga dalam pembentukkan konsep diri, di dalam lingkungan sekolah terdapat berbagai budaya yang berbeda hal ini terjadi karena para pendidik dan peserta didik berasal dari latar belakang budaya yang berbeda. Dampak dari perbedaan budaya tersebut terhadap peserta didik minoritas dapat membuat peserta didik mudah terpengaruh dan kehilangan identitas diri hal ini terjadi akibat perbedaan antara konsep dari dan latar belakang budaya yang telah dianut dengan budaya baru yang mereka hadapi, untuk itu dalam hal ini peran guru BK sangat dibutuhkan agar dapat membantu peserta didik sukses mencapai identitas dirinya, adapun upaya yang dapat dilakukan guru BK dalam membantu peserta didik minoritas tersebut adalah dengan menggunakan layanan konseling lintas budaya agar dapat membantu proses mendefinisikan tujuan yang konsisten dengan pengalaman hidup dan nilai-nilai budaya klien.

\section{DAFTAR PUSTAKA}

Anissa, Nova dan Handayani, Agustin. 2012. Hubungan Antara Konsep Diri dan Kematangan Emosi Dengan Penyesuaian Diri Istri Yang Tinggal Bersama Keluarga Suami. Jurnal Psikologi Pitutur, Vol. 1 (1), Hal 1-11

Danim, Sudarwan. 2010. Pengantar Kependidikan. Bandung : Alfabeta

Hurlock, Elizabeth B. 2010. Perkembangan Anak. Edisi Keenam: Jilid 2. Jakarta: Erlangga.

Hurlock, Elizabeth B. 2011. Psikologi Perkembangan, suatu pendekatan sepanjang rentang kehidupan. Edisi Kelima. Jakarta : Erlangga

KBBI, 2018. Kamus Besar Bahasa Indonesia (KBBI) [Online]. Tersedia di https://kbbi.web.id/minoritas, Diakses pada 17.25, 29 November 2018

Matsumoto, David and Juang, Linda. 2013. Culture \& Psychology $5^{\text {th }}$ Edition. USA: Wadsworth, Cengage Learning.

Mendatu, Achmanto. 2010. Prasangka Etnik. Yogyakarta: Psikoeduka.

Murmanto, Melanie D. 2007. Pembentukan Konsep Diri Siswa Melalui Pembelajaran Partisipatif. Jurnal Pendidikan Penabur Vo. VI, No.08

Peserta didik. 2018. Di Wikipedia, Ensiklopedia Bebas. Tersedia di https://id.wikipedia.org/w/index.php?title=Peserta_didik\&oldid=13702357

Diakses pada 16:42, 29 November 2018

Ratts, Manivong J and Pedersen, Paul B. 2014. Counseling For Multiculturalism and Social Justice Intergration, Theory, and Applicatio. Alexandria, VA:

American Counseling Association.

Sue, Deral, Wing, Jhon, David, Sue, 2008. Counseling the Culturally:Diverse Theoy and Practce (5th Ed.)New jersey. JhonWiley \& Sons, Inc.

Undang-undang Republik Indonesia No. 20. 2003. Sistem Pendidikan Nasional.Jakarta : BP Panca Usaha 
Waghmare, Ramesh D. 2018. Gender Difference Between Self-Concept. The International Journal of Indian Psychology. Vol. 6 (1), 1-12 DOI: $10.25215 / 0601.067$ 